\title{
Phenotypic Correlation, Path Analysis and Genetic Parameters of Some Quantitative Characters in Rice Under Water Stress Environments
}

\author{
El-Degwy, Ibrahim Saad ${ }^{1}$
}

\begin{abstract}
The present investigation was conducted at the Experimental Farm of Faculty of Agriculture, Kafrelsheikh University during 2008 and 2009 seasons. The main objectives of this investigation were to study the association between some quantitative characters in rice, using path coefficient analysis to determine the relative importance of such characters to grain yield variation and estimation of some genetic parameters of twenty five rice genotypes under water stress environments (irrigation every 6, 9 or 12 days).
\end{abstract}

Grain yield was positively correlated with each of number of panicles/plant (under the two severely stressed environments), number of grains/panicle (under the first and the third water intervals) and with panicle length under all environments. Panicle length was positively correlated with number of grains/panicles under all treatments.

Fertility percentage was negatively correlated with number of panicles/plant under all environments and positively correlated with 1000-grain weight under the first and the third treatments. Meanwhile, number of panicles/plant was negatively correlated with 1000-grain weight, this may be due to their compensatory relationship.

Path coefficient analysis revealed that under the most stressed environments, number of panicles/plant had the largest direct effect on grain yield, while under slight stress (irrigation every 6 days), number of grains/panicle appeared to be the most important yield component followed by number of panicles/plant and panicle length.

Phenotypic coefficient of variability (PCV) was, in general, higher than genotypic (GCV) coefficient of variability for different traits, indicating less environmental influence in the expression of different traits.

Heritability estimates in broad sense were either relatively moderate or high for all studied traits. Such estimates ranged from 55 to $94 \%$ for grain yield and 1000grain weight, respectively. Relatively higher genetic advance coupled with high heritability estimates was detected for 1000-grain weight and plant height.

\section{INTRODUCTION}

Grain yield is the most important character, it is the final outcome of the various metabolic activities occurred in the plant. The method most widely used in rice breeding is hybridization followed by selection in the segregated generation. Hence, the plant breeder needs to know what are the most important characters in selection for high yield. Some workers studied the relationships between grain yield and other agronomic traits.

Rice grain yield was positively correlated with each of heading date (Choudhury and Das, 1997); plant height (Takane, et al., 1997); panicle length (El-Hity and El-Keredy, 1992 and Yolanda and Das, 1995); number of panicles/plant (Ashvani et al., 1997); grain number/panicle (Anand, et al., 1998 and Rao and Saxena, 1999); and 1000-grain weight (El-Hity, et al., 1992).

Panicle length was positively correlated with each of plant height and number of spikelets/panicle (Chaubey and Singh, 1994) Also, plant height was positively correlated with number of grains/panicle (Gomez, et al., 2005).

Correlation, simply measures mutual association without regard to causation, while path analysis specifies the causes and measures their relative importance. Many efforts were conducted to study path analysis in rice such as Mishra, et al., (1973), Rao et al. (1976), Nigem and Eissa (1988), El-Hity and Keredy (1992), El-Hity (1994) and Samonte et al. (1998). The greatest direct positive effects for grain yield were recorded for number of panicles/plant followed by plant height (Chaubey, et al., 1994), while Yolanda and Das (1995) indicated that grain number per panicle was the main component character affecting yield directly.

Estimation of variability, heritability and predicted genetic gains of quantitative traits are important for available rice germplasm in breeding programs, to judge whether the phenotypic variability is heritable or due to the environment. The present paper deals with such type of analysis and its objectives were to study:

1. The interrelationships between grain yield and other characters studied as phenotypic correlation coefficients under three water stressed environments.

2. Path analysis to detect the relative importance of some morphological characters to yield variations under three water stressed environments.

3. Phenotypic (PCV) and genotypic (GCV) coefficients of variability, heritability and genetic advance from selection for the studied characters. 


\section{MATERIALS AND METHODS}

The present investigation was carried out at the Experimental Farm of the Faculty of Agriculture, Kafrelsheikh University during 2008 and 2009 seasons. Twenty five rice genotypes, lines and hybrids having diverse morphobgical and agronomical traits were involved in this study. Such genotypes were: Giza 171, Suweon 287R, Milang, Agmi, Giza 159, IR 66R, pusa 150-9-3-IR, IR 4467-3-2-2R, Sakha 104, Giza 177, Giza 181, Giza 182, Giza 178, Giza 176, Sakha 102, Sakha 103, Riho, Giza 175, Sakha 101, hybrid rice 1, hybrid rice 2, Giza 172, Gz. 1368-5-4, G 46B and G 46A x Giza 178 (as a promising hybrid rice combination).

Thirty days old seedlings of each genotypes were individually transplanted in seven rows, $5.8 \mathrm{~m}$ long and $20 \mathrm{~cm}$ apart. Each row contained twenty-nine hills. Sowing date were on 3 and 5 May in the two seasons, respectively. The seeds of G 46A x Giza 178 rice hybrid were produced in the summer season of 2007 through crossing the promising cytoplasmic male sterile line (G46A) with the indica rice cultivar (Giza 178). While, the two other hybrid rice combinations; hybrid rice 1 and hybrid rice 2, were kindly provided by Rice Research and Training Center, Sakha Kafr El-Sheikh, Egypt. All the genotypes were grown under three intervals of irrigation; watering every 6,9 or 12 days. A randomized complete block design with three replications was employed for each water interval.

The stress was applied after two weeks from transplanting till harvest. The package of all other recommendations of rice planting was followed.

Readings for individual characters were recorded on five center rows excluding the two outer rows from each plot. Ten guarded hills were randomly chosen and used for collecting data on yield components and some agronomic characters. The following characters were measured.

1. Days to $50 \%$ heading (day).

2. Plant height $(\mathrm{cm})$.

3. Panicle length $(\mathrm{cm})$.

4. Number of grains/panicle.

5. Fertility percentage (\%).

6. Number of panicles/plant.

7. 1000-grain weight (g).

8. Grain yield (ton/fed.).

Grain yield was calculated from the total weight of grains from each plot (five center rows) and then converted to calculate grain yield (ton/fed.).

Analysis of variance was computed for each season according to Snedecor and Cochran (1967). Error variances from separate analysis of the data were tested for homogeneity using Bartlett's Test (Bartlett, 1937). As such error was homogeneous the combined analysis was calculated for the data of the two seasons according to Cochran and Cox (1957). Phenotypic (PCV) and genotypic (GCV) of variability were estimated according to the method suggested by Burton (1952). The expected genetic advance from selection $(\Delta \mathrm{g})$ for a given trait as well as the phenotypic correlation between any pairs of traits was calculated as stated by Johnson et al. (1955). Moreover, path analysis was calculated as illustrated by Dewey and Lu (1959).

\section{RESULTS AND DISCUSSION}

The knowledge of degree and direction of correlation among different traits of rice are of great importance. It may be useful indicator for indirect selection programs as it help in identifying traits that have more, little or no importance in the selection programs. The phenotypic correlation coefficient between grain yield and the seven characters on one side, and among the agronomic characters themselves on the other side, are presented in Table 1. Obviously, grain yield was positive and highly significant correlated with number of panicles/plant under the second and the third water intervals ( 0.505 and 0.424 , respectively) and with number of grains/panicle and panicle length under all environments.

Previous papers have mentioned that rice grain yield as a function of number of sipkelets/panicle, grain weight, percentage of filled spikelets (Yoshida and Parao, 1976) and number of panicles per square meter (Miller et al., 1991) or number of filled grain per panicle (Samonte et al., 1998). Grain yield was positively correlated with number of spikelets/panicle and panicle length (Geethadevi et al., 2000).

Other inter-character correlations revealed that number of days to $50 \%$ heading was significantly and positively correlated with plant height under all environments. Such estimates were $0.379,0.392$ and 0.348 for $T_{1}, T_{2}$, and $T_{3}$, respectively. While, it was negatively correlated with fertility percentage and number of panicles/plant. These results were in general agreement with those reported by El-Hity (1994) who reported that heading date was positively correlated with culm length and negatively correlated with number of panicles per $\mathrm{m}^{2}$. Plant height exhibited positive and highly significant phenotypic correlation coefficients with fertility percentage under all environments.

Panicle length gave positive and significant correlation coefficient with number of grains/panicles under all environments. 
Table 1. Phenotypic simple correlation coefficient among the studied characters under three water intervals averaged over 25 rice genotypes and the two seasons

\begin{tabular}{|c|c|c|c|c|c|c|c|c|}
\hline \multirow[b]{2}{*}{ Characters } & \multirow[b]{2}{*}{$\begin{array}{l}\text { Water } \\
\text { intervals }\end{array}$} & \multicolumn{7}{|c|}{ Parametrs } \\
\hline & & $\begin{array}{c}\text { No. of days } \\
\text { to } 50 \% \\
\text { heading }\end{array}$ & Plant height & $\begin{array}{l}\text { Panicle } \\
\text { length }\end{array}$ & $\begin{array}{l}\text { No. of } \\
\text { grains/ } \\
\text { panicle }\end{array}$ & $\begin{array}{c}\text { Fertility } \\
\text { percentage }\end{array}$ & $\begin{array}{c}\text { No. of } \\
\text { panicles/ } \\
\text { plant }\end{array}$ & $\begin{array}{c}1000 \text { grain } \\
\text { weight }\end{array}$ \\
\hline \multirow{3}{*}{ Grain yield } & $\mathrm{T}_{1}$ & $-0.248^{*}$ & -0.080 & $0.383^{* *}$ & $0.448 * *$ & -0.058 & 0.133 & -0.053 \\
\hline & $T_{2}$ & -0.042 & -0.010 & $0.203^{*}$ & -0.069 & $-0.363 * *$ & $0.505^{* *}$ & -0.086 \\
\hline & $\mathrm{T}_{3}$ & 0.141 & 0.183 & $0.261^{*}$ & $0.404 * *$ & $-0.333 * *$ & $0.424 * *$ & -0.164 \\
\hline \multirow{3}{*}{$\begin{array}{l}\text { No. of days to } \\
50 \% \text { heading }\end{array}$} & $\mathrm{T}_{1}$ & & $0.379 * *$ & 0.060 & -0.058 & -0.128 & -0.166 & -0.120 \\
\hline & $\mathrm{T}_{2}$ & & $0.392 * *$ & 0.051 & -0.127 & $-0.233^{*}$ & $-0.266^{*}$ & -0.038 \\
\hline & $\mathrm{T}_{3}$ & & $0.348 * *$ & -0.026 & 0.005 & $-0.381 * *$ & -0.105 & -0.010 \\
\hline \multirow{3}{*}{ Plant height } & $\mathrm{T}_{1}$ & & & -0.139 & -0.130 & $0.482 * *$ & -0.069 & 0.117 \\
\hline & $\mathrm{T}_{2}$ & & & -0.037 & $-0.239 *$ & $0.481 * *$ & $-0.237 *$ & 0.111 \\
\hline & $\mathrm{T}_{3}$ & & & 0.042 & -0.024 & $0.305 * *$ & $-0.248^{*}$ & 0.101 \\
\hline \multirow{3}{*}{ Panicle length } & $\mathrm{T}_{1}$ & & & & $0.467 * *$ & -0.098 & 0.084 & 0.017 \\
\hline & $\mathrm{T}_{2}$ & & & & $0.250 *$ & -0.056 & 0.115 & 0.185 \\
\hline & $\mathrm{T}_{3}$ & & & & $0.445 * *$ & 0.015 & -0.006 & 0.088 \\
\hline \multirow{3}{*}{$\begin{array}{l}\text { No. of grains/ } \\
\text { panicle }\end{array}$} & $\mathrm{T}_{1}$ & & & & & -0.094 & -0.178 & 0.097 \\
\hline & $\mathrm{T}_{2}$ & & & & & -0.190 & 0.061 & 0.38 \\
\hline & $\mathrm{T}_{3}$ & & & & & -0.213 & 0.011 & 0.058 \\
\hline \multirow{3}{*}{$\begin{array}{c}\text { Fertility } \\
\text { percentage }\end{array}$} & $\mathrm{T}_{1}$ & & & & & & $-0.279 *$ & $0.291 *$ \\
\hline & $T_{2}$ & & & & & & $-0.342 * *$ & 0.180 \\
\hline & $\mathrm{T}_{3}$ & & & & & & $-0.335^{* *}$ & $0.382 * *$ \\
\hline \multirow{3}{*}{$\begin{array}{l}\text { No. of } \\
\text { panicles }\end{array}$} & $\mathrm{T}_{1}$ & & & & & & & $-0.412 * *$ \\
\hline & $\mathrm{T}_{2}$ & & & & & & & $-0.441 * *$ \\
\hline & $\mathrm{T}_{3}$ & & & & & & & $-0.232 *$ \\
\hline
\end{tabular}

$\mathrm{T}_{1}, \mathrm{~T}_{2}, \mathrm{~T}_{3}$ : refers to irrigation every 6,9 or 12 days, respectively.

$*$ and $* *$ significant at 0.05 and 0.01 levels, respectively.

Previous results showed that panicle length was positively correlated with number of productive tillers/m² (El-Hity and El-Keredy, 1992).

Fertility percentage showed negative and significant correlations with number of panicles/plant under all environments but, it was positively correlated with 1000-grain weight in case of the first water interval and the third one. While, number of panicles/plant and 1000grain weight were negatively correlated due to their compensatory relationship.

From the previous results of correlations, it is obvious that relationships between most pairs of traits were approximately constant and showed the same direction under all environments, suggesting the possibility of selection for common traits for genetic improvement of yield under wide range of environments (El-Marakby et al., 2007). Also, selection of genotypes with high mean performance for panicle length, number of grains/panicle and number of panicles/plant will lead to high yielding genotypes.

\section{Path coefficient analysis:}

Information on the interrelationship among the studied characters was obtained by path coefficient analysis of the phenotypic correlations. Path coefficient

analysis was practiced in order to find out the relative importance for the studied characters towards grain yield variations. Grain yield was considered the resultant variable and the other characters the causal variables.

Each component had a direct influence acting alone, and an indirect influence acting in combination with the other variables. Path coefficient analysis between grain yield and each one of the specified characters are presented in Table 2. It is clear from the results that plant height, panicle length, number of grains/panicle and number of panicles/plant showed positive direct effects on grain yield.

The direct effect of plant height was positive and moderate on grain yield under the three water intervals. The direct effects showing greater values with increasing water intervals, which amounted to 0.176 , 0.359 and 0.382 for the three water intervals, respectively. On the other hand, all the indirect effects of plant height were low or had negative values.

The positive correlation of panicle length with grain yield could mainly be attributed to its direct effect of grain yield. Such estimates were $0.252,0.18$ and 0.117 for the three water intervals, respectively. 
Table 2. Path coefficient analysis of direct and indirect effects on grain yield for three water intervals averaged over 25 rice genotypes and the two seasons

\begin{tabular}{|c|c|c|c|}
\hline \multirow{2}{*}{ Source of variation } & \multicolumn{3}{|c|}{ Water intervals (days) } \\
\hline & 6 & 9 & 12 \\
\hline \multicolumn{4}{|l|}{ Heading date $\left(\mathrm{X}_{1}\right)$ and grain yield } \\
\hline Direct effect $\left(\mathbf{P y _ { 1 }}\right)$ & -0.32 & -0.22 & -0.04 \\
\hline Indirect effect via plant height & 0.067 & 0.141 & 0.133 \\
\hline Indirect effect via panicle length & 0.015 & 0.009 & -0.003 \\
\hline Indirect effect via number of grains/panicle & -0.02 & 0.023 & 0.002 \\
\hline Indirect effect via fertility percentage & 0.01 & 0.115 & 0.093 \\
\hline Indirect effect via number of panicles/plant & -0.012 & -0.106 & -0.044 \\
\hline Indirect effect via 1000-grain weight & 0.012 & -0.004 & 0.001 \\
\hline Total correlation: $\mathbf{r}\left(\mathbf{x}_{1}, \mathbf{y}\right)$ & -0.248 & -0.042 & 0.141 \\
\hline \multicolumn{4}{|l|}{ Plant height $\left(\mathrm{X}_{2}\right)$ and grain yield } \\
\hline Direct effect $\left(\mathbf{P y}_{2}\right)$ & 0.176 & 0.359 & 0.382 \\
\hline Indirect effect via heading date & -0.121 & -0.086 & -0.014 \\
\hline Indirect effect via panicle length & -0.035 & -0.007 & 0.005 \\
\hline Indirect effect via number of grains/panicle & -0.045 & 0.043 & -0.007 \\
\hline Indirect effect via fertility percentage & -0.038 & -0.237 & -0.074 \\
\hline Indirect effect via number of panicles/plant & -0.005 & -0.094 & -0.104 \\
\hline Indirect effect via 1000-grain weight & -0.011 & 0.012 & -0.004 \\
\hline Total correlation: $\mathbf{r}\left(\mathbf{x}_{2}, \mathbf{y}\right)$ & -0.080 & -0.01 & 0.163 \\
\hline \multicolumn{4}{|l|}{ Panicle length $\left(X_{3}\right)$ and grain yield } \\
\hline Direct effect $\left(\mathrm{Py}_{3}\right)$ & 0.252 & 0.180 & 0.117 \\
\hline Indirect effect via heading date & -0.019 & -0.010 & 0.001 \\
\hline Indirect effect via plant height & -0.024 & -0.014 & 0.016 \\
\hline Indirect effect via number of grains/panicle & 0.163 & -0.046 & 0.137 \\
\hline Indirect effect via fertility percentage & 0.009 & 0.028 & -0.004 \\
\hline Indirect effect via number of panicles/plant & 0.006 & 0.046 & -0.003 \\
\hline Indirect effect via 1000-grain weight & -0.002 & 0.019 & -0.004 \\
\hline Total correlation: $\mathbf{r}\left(\mathbf{x}_{3}, \mathbf{y}\right)$ & 0.383 & 0.203 & 0.261 \\
\hline \multicolumn{4}{|l|}{ No. of grains/panicle $\left(\mathrm{X}_{4}\right)$ and grain yield } \\
\hline Direct effect $\left(\mathbf{P y}_{4}\right)$ & 0.348 & -0.178 & 0.307 \\
\hline Indirect effect via heading date & 0.019 & -0.028 & 0.000 \\
\hline Indirect effect via plant height & -0.022 & -0.086 & -0.009 \\
\hline Indirect effect via panicle length & 0.118 & 0.095 & 0.052 \\
\hline Indirect effect via fertility percentage & 0.008 & 0.093 & 0.052 \\
\hline Indirect effect via number of panicles/plant & -0.013 & 0.024 & 0.005 \\
\hline Indirect effect via 1000-grain weight & -0.01 & 0.004 & -0.002 \\
\hline Total correlation: $\mathbf{r}\left(\mathbf{x}_{\mathbf{4}}, \mathbf{y}\right)$ & 0.448 & -0.069 & 0.404 \\
\hline \multicolumn{4}{|l|}{ Fertility percentage $\left(\mathrm{X}_{5}\right)$ and grain yield } \\
\hline Direct effect $\left(\mathbf{P y}_{5}\right)$ & -0.078 & -0.492 & -0.244 \\
\hline Indirect effect via heading date & 0.040 & 0.051 & 0.015 \\
\hline Indirect effect via plant height & 0.085 & 0.173 & 0.117 \\
\hline Indirect effect via panicle length & -0.025 & -0.012 & 0.002 \\
\hline Indirect effect via number of grains/panicle & -0.033 & 0.034 & -0.065 \\
\hline Indirect effect via number of panicles/plant & -0.020 & -0.136 & -0.141 \\
\hline Indirect effect via 1000-grain weight & -0.029 & 0.019 & -0.015 \\
\hline Total correlation: $\mathbf{r}\left(\mathbf{x}_{5}, \mathbf{y}\right)$ & -0.058 & -0.363 & -0.333 \\
\hline \multicolumn{4}{|l|}{ No. of panicles/plant $(\mathrm{x6})$ and grain yield } \\
\hline Direct effect $\left(\mathbf{P y}_{6}\right)$ & 0.071 & 0.399 & 0.420 \\
\hline Indirect effect via heading date & 0.053 & 0.059 & 0.004 \\
\hline Indirect effect via plant height & -0.012 & -0.085 & -0.095 \\
\hline Indirect effect via panicle length & 0.021 & -0.021 & -0.001 \\
\hline Indirect effect via number of grains/panicle & -0.062 & -0.011 & 0.003 \\
\hline Indirect effect via fertility percentage & 0.022 & 0.168 & 0.082 \\
\hline Indirect effect via 1000-grain weight & 0.040 & -0.046 & 0.009 \\
\hline Total correlation: $\mathbf{r}\left(\mathbf{x}_{6}, y\right)$ & 0.133 & 0.505 & 0.424 \\
\hline \multicolumn{4}{|l|}{ 1000-grain weight $\left(\mathrm{x}_{7}\right)$ and grain yield } \\
\hline Direct effect $\left(\mathbf{P y}_{7}\right)$ & -0.098 & 0.104 & -0.040 \\
\hline Indirect effect via heading date & 0.038 & 0.008 & 0.000 \\
\hline Indirect effect via plant height & 0.021 & 0.040 & 0.039 \\
\hline Indirect effect via panicle length & 0.004 & 0.033 & 0.010 \\
\hline Indirect effect via number of grains/panicle & 0.034 & -0.007 & 0.018 \\
\hline Indirect effect via fertility percentage & -0.023 & -0.089 & -0.093 \\
\hline Indirect effect via number of panicles/plant & -0.029 & -0.176 & -0.097 \\
\hline Total correlation: $\mathbf{r}\left(\mathbf{x}_{7}, \mathbf{y}\right)$ & -0.053 & -0.086 & -0.164 \\
\hline
\end{tabular}


The direct effects of this trait were very low via fertility percentage and number of panicles/plant under the first and the second water intervals and under the third water intervals via heading date and plant height. Previous results showed a positive direct effect of panicle length on grain yield (El-Hity and El-Keredy, 1992).

Number of grains/panicle had the largest direct effect on grain yield, as confirmed by the highly significant and positive phenotypic correlation coefficient between the two characters $(0.448)$. The indirect effect of number of grains/panicle via panicle length was low (0.118) under the first water interval and very low or had negative values via the other traits and the other environments. The indirect effect via number of panicles/plant and 1000grain weight was negative.

The negative indirect effects obtained between number of grains/panicle and number of panicles/plant, this could be due to the masking action on direct effect influence (El-Hity et al., 1992).

Number of grains/panicle proved to have a sizable effect on grain yield, while the indirect effect via the other characters were low and being negative (Nigem and Eissa, 1988). This results were in accordance with those also obtained by Samonte et al. (1998).

Fertility percentage showed a negligible direct effect on grain yield under the three water intervals as it showed negative values. The indirect effects of fertility percentage via plant height was positive and relatively low under the second and the third water intervals. Meantime, the indirect effect of this trait was very low via heading date and plant height under the first water intervals and under the second one via heading date, number of grains/panicle and 1000-grain weight. The indirect effect was mostly equal zero via panicle length (0.002). These results were generally in agreement with those of El-Hity and ElKeredy (1992) who reported that fertility percentage exhibited a negative direct effect on grain yield.

The direct effect of number of panicles/plant was positive and low under the first water intervals (0.071), relatively high (0.399 and 0.42) under the two other intervals, respectively. The indirect effect of this trait was relatively low (0.168) via fertility percentage and very low via the other combination or had negative values.

The direct effect of 1000-grain weight was positive and low under the intermediate water interval. While such estimates were inferior and negative $(-0.098$ and -0.04$)$ under the first and the third water intervals, respectively. The indirect effects of 1000-grain weight via heading date, plant height and panicle length were very low under the three environments and via number of grains/panicle under the third water interval. Meanwhile, all the other indirect effects of 1000-grain weight had negative values.

The aforementioned results indicated that a plant type for increased yield should have large panicles, high number of grains/panicle and high number of panicles/plant as it have a possible consideration for the indirect selection for grain yield.

\section{Genetic Parameters:}

Estimates of variance components, phenotypic (PCV) and genotypic (GCV) coefficient of variability and genetic advance are presented in Table 3 . The results showed that genotypic variance $\left(\delta^{2} \mathrm{~g}\right)$ were highly significant for all the studied characters, indicating wide range of genetic variability among rice genotypes. Also, genotype by environment interaction was highly significant for all the studied characters indicated that the genotypes interacted considerably with environmental changes.

Phenotypic coefficient of variability was, in general, higher than genotypic coefficient of variability. The small differences between PCV and GCV indicating less environmental influence on the expression of different traits. Such estimates were (17.0 and 13.62) for number of panicles/plant, (14.72 and 13.62) for number of panicles/plant and (14.72 and 10.47) for grain yield for PCV and GCV, respectively. The relatively high genetic coefficients of variability for grain yield and number of panicles/plant indicated that these traits might be more genotypically predominant and it would be possible to achieve further improvement from them. Choudhary and Das (1998) found that grain yield per plant had a high genotypic coefficient of variability.

Results in Table 3 showed that heritability estimates in broad sense, were either relatively moderate or high for the studied traits. Such estimates was high in case of 1000-grain weight (94\%). while, it was relatively high for days to $50 \%$ heading $(87.64 \%)$, plant height $(88.4 \%)$ and fertility percentage $(83.52 \%)$. Moderate heritability estimates were recorded for panicle length, number of grains/panicle, number of panicles/plant and grain yield (56.1, 66.07, 64.57 and 55\%, respectively).

Results in Table 3 showed that the expected genetic advance (GS) from selection, as percentage of mean, ranged from 10.71 to $23.72 \%$ for fertility percentage and plant height, respectively, while such values were relatively moderate for grain yield, 1000-grain weight and number of panicles/plant. The desirable genetic gain was found to be associated with high heritability estimates in case of 1000-grain weight or with moderate heritability estimates in case of grain yield. 
Table 3. Genetic parameters for eight agronomic rice characters averaged over 25 rice genotypes, the three water intervals and the two seasons

\begin{tabular}{|c|c|c|c|c|c|c|c|c|}
\hline Parameters & $\begin{array}{c}\text { No. of days } \\
\text { to } 50 \% \\
\text { heading } \\
\end{array}$ & $\begin{array}{l}\text { Plant } \\
\text { height }\end{array}$ & $\begin{array}{l}\text { Panicle } \\
\text { length }\end{array}$ & $\begin{array}{l}\text { No. of } \\
\text { grains/ } \\
\text { panicle }\end{array}$ & $\begin{array}{c}\text { Fertility } \\
\text { percentage }\end{array}$ & $\begin{array}{c}\text { No. of } \\
\text { panicles/ } \\
\text { plant }\end{array}$ & $\begin{array}{c}1000 \text { grain } \\
\text { weight }\end{array}$ & $\begin{array}{c}\text { Grain } \\
\text { yield }\end{array}$ \\
\hline Grand mean & 103.63 & 94.37 & 21.77 & 124.82 & 86.07 & 17.17 & 24.70 & 2.93 \\
\hline$\sigma^{2} g$ & 66.41 & 133.54 & 4.00 & 81.99 & 23.98 & 5.51 & 4.69 & 0.11 \\
\hline$\sigma^{2} \mathrm{gE}$ & 6.67 & 12.64 & 2.23 & 38.10 & 3.68 & 2.37 & 0.28 & 0.08 \\
\hline$\sigma^{2} \mathbf{e}$ & 2.70 & 4.88 & 0.90 & 4.00 & 1.05 & 0.70 & 0.01 & 0.01 \\
\hline P.C.V.\% & 8.40 & 13.03 & 12.24 & 8.92 & 6.22 & 17.00 & 9.02 & 14.72 \\
\hline G.C.V.\% & 7.86 & 12.25 & 9.17 & 7.25 & 5.69 & 13.62 & 8.75 & 10.47 \\
\hline $\mathbf{h}_{\text {b.s }}^{2}$ & 87.64 & 88.40 & 56.10 & 66.07 & 83.52 & 64.57 & 94.00 & 55.0 \\
\hline$\Delta \mathbf{g}$ & 15.78 & 22.38 & 3.09 & 15.16 & 9.22 & 3.90 & 4.32 & 0.51 \\
\hline $\mathrm{g}(\%$ of mean $)$ & 15.23 & 23.72 & 14.17 & 12.15 & 10.71 & 22.63 & 17.46 & 16.72 \\
\hline
\end{tabular}

Previous studies showed that heritability estimates were recorded for plant height (Saravanan and Senthil,1997).

Sadhukhan and Chattopadhyay (200) reported that grain yield had high phenotypic and genotypic coefficients of variation. El-Mowafi and Abou Shousha (2003) reported that heritability estimates were high for 1000-grain weight and moderate for number of spikelets/panicle, while grain yield exhibited low heritability estimates. High heritability estimates coupled with high genetic advances were recorded for plant height. (Gomez and Kalamani, 2003).

From the aforementioned results it is clear that the relationships between most pairs of traits were approximately constant and showed the same directions under all environments, suggesting the possibility of selection for common traits for genetic improvement of yield under wide range of environments.

Also, a plant type for increasing grain yield should have large panicles, high number of grains/panicle and high number of panicles/plant as it have a sizable effect on grain yield.

\section{REFERENCES}

Ashavani, P., R.K. Sharma; R.P.S. Dhaka; K.P.S. Arya and A. Panwar (1997). Correlation of yield and yield components in rice (Oryza sativa L.). Advances in Plant Sciences 10(1): 217-220.

Bartlett, M.S. (1937). Properties of sufficiency and statistical tests. Proc. Roy. Soc. London, Series A. (160): 268-282.

Burton, G.W. (1952). Quantitative inheritance in grasses. Proc. $6^{\text {th }}$ Int. Grassid Congr. (1): 227-283.

Chaubey, P.K. and R.P. Singh (1994). Genetic variability, correlation and path analysis of yield components of rice. Madras Agricultural Journal 81(9): 468-470.

Choudhary, P.D. and P.K. Das (1998). Genetic variability and correlation between quality and physico-chemical properties of high grain quality in rice. Chinese J. Rice. Sci. 11(2): 7076.
Choudhury, P.K.D. and P.K. Das (1997). Genetic variability, correlation and path coefficient analysis in deep water rice. Journal of the Agricultural Science Society of North East India, 10(1): 155-157.

Cochran, W.G. and G.M. Cox (1957). Experimental Design $2^{\text {nd }}$ Ed. John Wiley, N.Y.

Dewey, D.R. and K.H. Lu (1959). A correlation and path coefficient analysis of components of crested wheat grass seed production. Agron. J. 51: 515-518.

El-Hity, M.A. (1994). Performance of some rice cultivars (Oryza sativa L.) as affected by fertilization and plant spacing. II. Path coefficient analysis for yield and some yield components under different environmental conditions. J. of Agric. Res., Tanta Univ., 20(4): 688-701.

El-Hity, M.A. and M.S. El-Keredy (1992). Genotypic variability, phenotypic correlations and path coefficient analysis for grain yield and its components in rice (Oryza sativa L.). Journal of Agricultural Research, Tanta Univ., 18(2): 299-312.

El-Hity, M.A.; M.S. El-Keredy and A.G. Abdel-Hafez (1992). Phenotypic and genotypic variability in rice genotypes (Oryza sativa L.). Proc. $5^{\text {th }}$ Conf. Agron. Zagazig Univ., 1315 Sept., Vol. (1): 162-173.

El-Marakby, A.M.; A.A. Mohamed; Afaf M. Tolba and S.H. Saleh (2007). Correlation and path coefficient analysis for some traits in diallel crosses of bread wheat under different environments. Egypt. J. Plant Breeding (1): 101-113.

El-Mowafi, H.F. and A.A. Abou Shousha (2003). Combining ability and heterosis analysis of diverse CMS lines in hybrid rice. J. Agric. Res. Tanta Univ., 29(1): 106-127.

Geethadevi, T.; G. Andani; M. Krishnappa; B.T.R. Babu and A. Gowda (2000). Effect of nitrogen and spacing on growth and yield of hybrid rice. Gurrent Res. Univ., Agric. Sci., Bangalore 29 (5-6): 73-75.

Gomez, S.M. and A. Kalamani (2003). Scope of land races for future tolerance breeding programme in rice (Oryza sativa L.). Plant Archives 3(1): 77-79.

Gomez, S.M., C.R.Anandkumar and A. Kalamani (2005). Back ground trait analysis in drought resistant rice (Oryza sativa L.). cultures. Advances in Plant 18(1): 379-381. 
Johnson, H.W., H.F. Robinson and R.E. Comstock (1955). Estimates of genetic and environmental variability in Soybean. Agron. J. 47: 314-318.

Miller, B.C.; J.E. Hill and S.R. Roberts (1991). Plant population effects on growth and yield in water seeded rice. Agron. J. 83: 291-297.

Mishra, K.N.; J.S. Nanda and R.C. Chaudhary (1973). Correlation, path coefficient and selection indices in dwarf rice. Indian. J. Agric. Sci., 43: 306-311.

Nigem, S.A. and M.M.I. Eissa (1988). Genotypic association and path coefficient analysis in some rice crosses. Zagazig. J. Agric. Res. 15(2): 441-458.

Rao, C.S., K. Sahu and A.K. Ghosh (1976). Association of morphological characters and path coefficient analysis in rice. Oryza (13): 81-85.

Rao, S.S. and R.R. Saxena (1999). Correlation and regression analysis in upland rice. Oryza 36(1): 82-84.
Sadhukhan, R.N. and P. Chattopadhyay (2000). Variability and character association between yield attributes and grain quality in aromatic rice. J. of Interacademicia 4(4): 494-497.

Samonte, S.O.; L.T. Wilson and A.M. McClung (1998). Path analysis of yield and yield related traits of fifteen diverse rice genotypes. Crop Science 38: 1130-36.

Saravanan, R. and N. Senthil (1997). Genotypic and phenotypic variability, heritability and genetic advance in some important traits in rice. Madras Agric. J. 84(5): 276-277.

Snedecor, G.W. and W.G. Cochran (1967). Statistical methods. Iowa State Univ., Press, USA.

Takane M.; Y. Futsuhara; F. Kikuchi and H. Yamaguchi (1997). Inheritance of morphological characters. Science of Rice Plant. Vol.(3) Genetics. Food and Agriculture policy Research Center, Tokyo.

Yolanda, J.L. and L.D.V. Das (1995). Correlation and path analysis in rice (Oryza sativa L.). Madras Agricultural Journal 82(11): 576-578.

Yoshida, S. and F.T. Parao (1976). Climatic influence on yield and yield components of lowland rice in the tropics. p. 471494. In Climate and rice. IRRI, Los Banos, Philippines. 


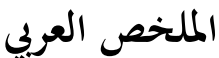

\section{التلازم المظهرى ومعامل المرور والمقاييس الوراثية لبعض الصفات الكمية في الأرز تحت بيئات من الإجهاد المائى}

$$
\text { إبراهيم سعد الدجوى }
$$

وعدد الحبوب بالدالية (فى المعاملتين الأولى والثالثة، أى عند الرى

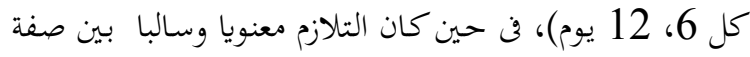

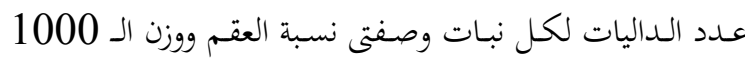
حبة تحت كل البيئات.

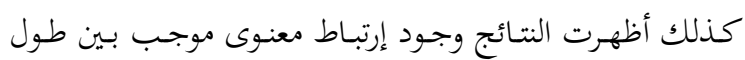
الدالية وعدد الحبوب بالدالية تحت معاملات الرى الثلاث. - أظهر تحليل معامل المرور أنه تحت ظروف شدة شيد الجفاف (الرى كل

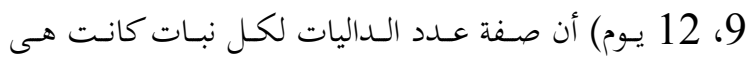
الأكثر تأثيرا مباشرا في تباين كمية المحصول في حين ظهر أنه تحت النه

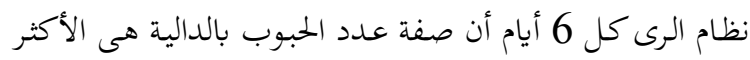
مساهمة وتلى ذلك عدد الداليات/نبات وطول الدالية.

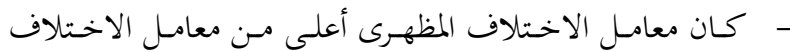

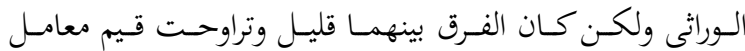
الاخستلاف الـوراثى مـن 5.69 إلى 13.62\% لصـفتى نسـبة الخصوبة وعدد الداليات/نبات على التوالى. - كانت قيم المكافئ الوراثى بصفة عامة إما متوسطة نسبيا أو عالية

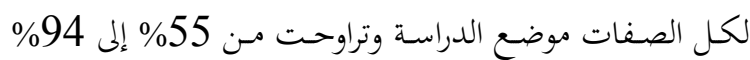

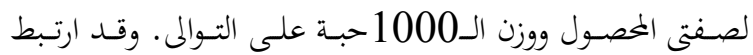

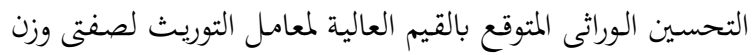

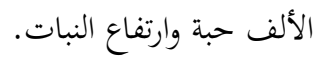

أقيمـت هـذه الدراسـة بالمزرعـة التجريبيـة بكليـة الزراعـة- جامعـة كفرالشيخ خـلال مـوسمى 2008-2009م. وتهـدف هـذه الدراسـة

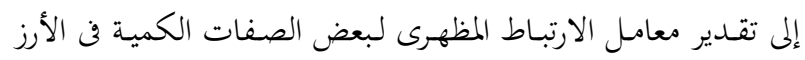

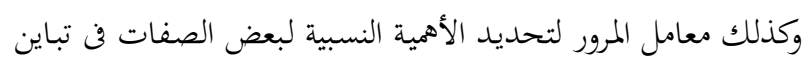
صفة المحصول بالإضافة لدراسة بعض المقاييس الوراثية. واشتملت هذه الدراسة على خمسة وعشرون صنفا وسلالة محلية

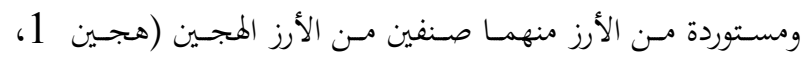
هجين 2) وأيضا أحد تراكيب الأرز الهجين المبشرة .(G 46A x Giza 178) تم زراعـة هــه التراكيـب الوراثيـة الخمسس والعشـرون تحـت ثـلاث

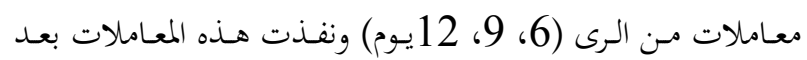

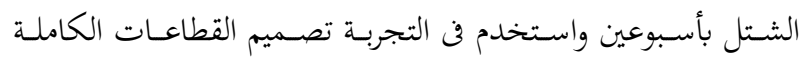
العشوائية في ثلاث مكررات. وكانت أهم النتائج المتحصل عليها هى:

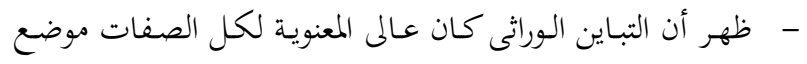

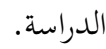
- كان هناك تلازما موجبا ومعنويا بين كمية المصصول وبين صفة عدد الداليات/ نبات (تحت ظروف الرى كل 9، 12 يوم) 